УДК 615.214.32.083.75

DOI https://doi.org/10.11603/2312-0967.2019.3.10408

\title{
ДОСЛІДЖЕННЯ АСИМЕТРІЇ ІНФОРМАЦІї НОРМАТИВНИХ ДОКУМЕНТІВ ЩОДО ЛІКАРСЬКИХ ЗАСОБІВ ДЛЯ ФАРМАКОТЕРАПІЇ ДЕПРЕСИВНИХ РОЗЛАДІВ У ВАГІТНИХ І ПОРОДІЛЬ
}

\author{
Б. П. Громовик, М. Є. Матвійчук \\ Львівський національний медичний університет імені Данила Галицького \\ hromovyk@gmail.com,maryana_matviychuk@ukr.net
}

ІНФОРМАЦІЯ

Надійшла до редакції / Received: 22.08.2019

Після доопрацювання / Revised: 05.09.2019

Прийнято до друку / Accepted: 12.09.2019

\section{Ключові слова:}

депресія;

жінка до- і післяпологовий

періоди; антидепресант;

антипсихотик;

анксіолітик;

торгова марка;

фрормулярна стаття; інструкція

для медичного застосування;

асиметрія інформації.

\section{АНОТАЦІЯ}

Мета роботи. Порівняльний аналіз змісту текстів формулярних статей Державного формуляра лікарських засобів (ДФ ЛЗ) та інструкцій для медичного застосування (IM3) антидепресантів, антипсихотиків та анксіолітиків, призначених для фрармакотерапії (ФТ) депресивних розладів (ДР) у жінок, для убезпечення від потенційних ризиків ФТ у діаді мати - плід/ дитя.

Матеріали і методи. Матеріали дослідження: дані Уніфікованого клінічного протоколу первинної, вторинної та третинної медичної допомоги для лікування депресії, ДФ ЛЗ одинадцятого випуску, Державного реєстру лікарських засобів (ДР Л3) України станом на 10.08.2019, зокрема IM3 ТМ антидепресантів, антипсихотиків та анксіолітиків. У роботі використано методи контекстуального аналізу, порівняння, узагальнення.

Результати й обговорення. За даними вивчення Унісікованого клінічного протоколу для ФТ депресії показано 18 антидепресантів, 19 антипсихотичних засобів і 2 анксіолітики за міжнародною непатентованою назвою. При цьому в Україні зареєстровано 80 антипсихотичних засобів, антидепресантів - 101, анксіолітиків - 9 торгових марок (ТМ). У свою чергу, у ДФ ЛЗ одинадцятого випуску внесено 69 ТМ антипсихотичних засобів, 71 ТМ антидепресантів і 8 ТМ анксіолітиків. В Україні не зареєстровано жодної ТМ Оксазепаму та Хлордіазепоксиду, а також 15 ТМ досліджуваних Л3 з 12 підгруп хімічних речовин, хоча вони присутні у ДФ ЛЗ. При цьому в ДФ ЛЗ не включені ТМ 3 підгрупи Тіанептину.

Аналіз змісту текстів фрормулярних статей та IMЗ ЛЗ, включених у ДФ ЛЗ, показав що у 128 TM, а саме: 65 TM 318 підгруп антипсихотиків, 6 TM з 2 підгруп анксіолітиків та 57 TM з 16 підгруп антидепресантів, спостерігається розходження 3 фрормулярними статтями в частині інорормації щодо застосування у жінок при вагітності та у період грудного вигодовування. Серед них лише для ТМ Амісульприду вказано на протипоказання при годуванні груддю, але не зазначено застереження щодо періоду вагітності. При вивченні особливостей застосування ІМЗ досліджуваних ТМ виявлено 33 тези стосовно періоду вагітності та 21 - щодо грудного вигодування, які містять стилістичні та семантичні розбіжності в тлумаченні цих постулатів. Для унісрікації зазначені сукупності застережень були згруповані по 5 груп відповідно в період вагітності та в період годування груддю.

Також виявлено значні різночитання змісту тексту в більшості ІМЗ ТМаналогів щодо застосування у період вагітності та годування груддю,

ISSN 2312-0967. Pharmaceutical review. 2019. № 3 
окрім ТМ Амісульприду, Зуклопентиксолу, Сульпіриду, Флюпентиксолу, Хлорпромазину, Клозапіну, Буспірону, Есциталопраму, Кломіпраміну, Пароксетину, Сертраліну, Тразодону, Флуоксетину, Флувоксаміну, Циталопраму (обидва періоди), Доксепіну, Дулоксетину (грудне годування), Венлафаксину (при вагітності).

Висновки. На підставі порівняльного аналізу змісту текстів фрормулярних статей ДФ ЛЗ та ІМЗ антидепресантів, антипсихотиків та анксіолітиків встановлені їх семантичні та стилістичні розбіжності, що при ФТ ДР у жінок у випадку вагітності та грудного вигодовування може спричинити ризик несприятливого впливу на перебіг процесу вагітності, а також до ризику негативного впливу на ембріон / плід та новонародженого і немовля. Для мінімізації асиметрії інформації (розбіжностей у тлумаченні особливостей застосування) у формулярних статтях ДФ ЛЗ та ІМЗ ТМ-аналогів Державному експертному центру МОЗ України варто здійснити уніфрікацію підходів до стилістики та семантики текстового наповнення відповідних розділів зазначених нормативних документів.

Вступ. Згідно з епідеміологічними дослідженнями останнього десятиліття, встановлено швидке поширення депресивних і тривожних розладів у жінок під час вагітності та після пологів. Так, близько $40 \%$ вагітних мають ознаки психопатології, більшість 3 них становлять депресії [6]. Депресивний розлад (ДР) спостерігається у $50-80$ \% жінок, які народили вперше, при цьому в кожної десятої породіллі він може мати інтенсивний та затяжний характер і стати початком розвитку післяпологової депресії [4].

Для фрармакотерапії (ФТ) депресії використовують антидепресанти, антипсихотичні засоби та анксіолітики [8]. Ці лікарські засоби (Л3), насамперед антидепресанти, не $€$ серйозними тератогенами, але вони можуть бути пов'язані з ускладненнями у новонароджених. Тому головний принцип ФТ під час вагітності та після пологів: низький ризик приймання ЛЗ для плода та новонародженого необхідно порівняти з користю лікування [1].

Відповідно до нормативних документів:

- офріційно затвердженою інорормацією про медичне застосування Л3, що супроводжує готовий Л3, є інструкція для медичного застосування (IM3) Л3 [5];

- джерелом наповнення формулярної статті Державного формуляра лікарських засобів (ДФ ЛЗ) $є$ чинна IMЗ оригінального ЛЗ, зареєстрованого в Україні; за відсутності реєстрації в Україні оригінального Л3 використовується IMЗ генеричного ЛЗ, який вперше був зареєстрований в Україні [3].

Проте наявність на фрармацевтичному ринку України багатьох торгових марок (ТМ) одного й того ж ЛЗ за міжнародною непатентованою назвою (МHH) та механізм формування формулярних статей може призвести до комунікативної розбіжності в текстах IM3 та фрормулярних статей. Так, на підставі порівняльного вивчення IM3 різних ТМ Небівололу [7], Метадону і Морфіну [9] встановлено наявність значних різночитань у деяких розділах досліджуваних текстів, зокрема що стосується застосування ЛЗ у період ва- гітності та/або грудного вигодовування. Така асиметрія інформації може призвести до ризику несприятливого впливу ФТ на перебіг процесу вагітності, а також до ризику негативного впливу на ембріон / плід та новонародженого і немовля.

Мета роботи - порівняльний аналіз змісту текстів формулярних статей ДФ ЛЗ та ІМЗ антидепресантів, антипсихотиків та анксіолітиків, призначених для ФТ ДР у жінок, для убезпечення від потенційних ризиків у діаді мати - плід/дитя.

Матеріали і методи. Матеріали дослідження: дані Уніфікованого клінічного протоколу первинної, вторинної та третинної медичної допомоги для лікування депресії [8], ДФ Лз одинадцятого випуску [6], Державного реєстру лікарських засобів (ДР ЛЗ) України станом на 10.08.2019, зокрема IMЗ ТМ антидепресантів, антипсихотиків та анксіолітиків [2]. У роботі використано методи контекстуального аналізу, порівняння, узагальнення.

Результати й обговорення. За даними вивчення нормативного документа [8] для ФТ депресії показана низка Лз за МНH, а саме 18 антидепресантів, 19 антипсихотичних засобів і 2 анксіолітики. Їхній перелік наведено в таблиці 1. При цьому, за даними таблиці, в Україні зареєстровано 80 антипсихотичних засобів, антидепресантів - 101, анксіолітиків - 9 ТМ. У свою чергу, у ДФ ЛЗ одинадцятого випуску внесено 69 ТМ антипсихотичних засобів, 71 ТМ антидепресантів і 8 ТМ анксіолітиків. Проте в Україні не зареєстровано жодної TM N05BA04 Оксазепаму та N05B A02 Хлордіазепоксиду, а також 15 TM 312 підгруп хімічних речовин, хоча вони присутні у ДФ Л3, а саме:

- N05A X08 Рисперидон - Рисперон® (Актавісехс, Ісландія; Балканфарма Дупниця АД, Болгарія), Рисполепт® та Рисполепт® квіклет (Янссен-Сілаг С.п.А., Італія).

- N05A H02 Клозапін - Лепонекс® (Новартіс Фармасьютикалс ЮК Лтд / Новартіс Саглік, Гідаве Тарім

ISSN 2312-0967. Фармацевтичний часопис. 2019. № 3 
Таблиця 1

Лікарські засоби для лікування депресивних розладів

\begin{tabular}{|c|c|c|c|c|c|c|c|}
\hline \multirow[b]{2}{*}{ МНН ЛЗ } & \multirow[b]{2}{*}{ Код АТХ } & \multicolumn{2}{|c|}{ К-ть TM } & \multirow[b]{2}{*}{ МНН ЛЗ } & \multirow[b]{2}{*}{ Код АТХ } & \multicolumn{2}{|c|}{ К-ть TM } \\
\hline & & ДР ЛЗ & ДФ ЛЗ & & & ДР лЗ & ДФ ЛЗ \\
\hline \multicolumn{2}{|c|}{ N05A Антипсихотичні засоби } & 80 & 69 & Оксазепам & N05BA04 & - & - \\
\hline Амісульприд & N05A L05 & 6 & 4 & Хлордіазепоксид & N05B A02 & - & - \\
\hline Арипіпразол & N05A X12 & 12 & 10 & \multicolumn{2}{|c|}{ N06A Антидепресанти } & 101 & 71 \\
\hline Галоперидол & N05A D01 & 4 & 3 & Агомелатин & N06A X22 & 1 & 1 \\
\hline Зипразидон & N05A E04 & 1 & 1 & Амітриптилін & N06A A09 & 6 & 6 \\
\hline Зуклопентиксол & N05A F05 & 3 & 3 & Бупропіон & N06A X12 & - & 1 \\
\hline Кветіапін & N05A H04 & 10 & 9 & Венлафраксин & N06A X16 & 10 & 7 \\
\hline Клозапін & N05A H02 & 2 & 3 & Доксепін & N06AA12 & 2 & 2 \\
\hline Оланзапін & N05A H03 & 8 & 7 & Дулоксетин & N06A X21 & 13 & 6 \\
\hline Паліперидон & N05A X13 & 2 & 1 & Есциталопрам & N06A B10 & 18 & 16 \\
\hline Рисперидон & N05A X08 & 13 & 12 & Іміпрамін & N06AA02 & 1 & 1 \\
\hline Сертиндол & N05A E03 & 1 & 1 & Кломіпрамін & N06AA04 & 3 & 2 \\
\hline Сульпірид & N05A L01 & 7 & 5 & Міансерин & N06A X03 & 2 & 2 \\
\hline Трифллуоперазин & N05A B06 & 3 & 2 & Міртазапін & N06A X11 & 5 & 6 \\
\hline Тіоридазин & N05A C02 & 1 & 1 & Пароксетин & N06A B05 & 4 & 4 \\
\hline Флуфреназин & N05A B02 & 1 & 1 & Сертралін & N06A B06 & 9 & 7 \\
\hline Флюпентиксол & N05A F01 & 2 & 2 & Тіанептин & N06A X14 & 1 & - \\
\hline Хлорпромазин & N05AA01 & 7 & 4 & Тразодон & N06A X05 & 2 & 2 \\
\hline Хлорпротиксен & N05A F03 & 1 & 1 & Флуоксетин & N06A B03 & 3 & 3 \\
\hline Літій & N05A N01 & 1 & 1 & Флувоксамін & N06A B08 & 2 & 2 \\
\hline \multicolumn{2}{|c|}{ N05B Анксіолітики } & 9 & 8 & Циталопрам & N06A B04 & 19 & 3 \\
\hline Буспірон & N05B E01 & 3 & 2 & \multirow{2}{*}{\multicolumn{2}{|c|}{ Разом }} & \multirow{2}{*}{191} & \multirow{2}{*}{148} \\
\hline Діазепам & N05B A01 & 6 & 6 & & & & \\
\hline
\end{tabular}

Урунлері Сан. Ве Тік. А.С., Великобританія / Туреччина);

- N05A H03 Оланзапін - Зипрекса® (Ліллі C.A., Icпанія/США);

- N05B А01Діазепам - Реланіум ${ }^{\circledR}$ (ВФ3 Польфа

АТ, Польща);

- N06A B04 Циталопрам - Прам® (Г.Л. Фарма ГмбХ, Австрія).

- N06A B05 Пароксетин - Пароксетин (Медокемі Лтд (Завод AZ), Кіпр);

- N06A B10 Есциталопрам - Есциталопрам Сандоз® (Сандоз Прайв ет Лімітед /Лек С.А., Індія/Польща) та Езопрекс (Ейч.Бі.Ем. Фарма, с.р.о. Словацька Республіка);

- N06A X12 Бупропіон - Велбутрин ${ }^{\mathrm{TM}}$ SR (ГлаксоСмітКляйн Фармасьютикалз С.А. /ГлаксоСмітКляйн, Польща/США);

- N06A X16 Венлафраксин - Віпакс XR (Дексель Лтд, Ізраїль);

- N06A Х03Міансерин - Леривон (Н.В.Органон, Нiдерланди);

- N06A B03 Флуоксетин - Продеп (Сан Фармасьютикал Індастріз Лтд, Індія);
- N06A X11Міртазапін - Міртел® (Г.Л. Фарма ГмбХ, Австрія).

При цьому в аналізований ДФ ЛЗ не включені ТМ 3 підгрупи N06A X14 Тіанептин.

Подальший аналіз змісту текстів формулярних статей та IMЗ Л3, включених у ДФ ЛЗ, показав (табл. 2), що у 128 ТМ, а саме: 65 TМ 318 підгруп антипсихотиків, 6 TM із 2 підгруп анксіолітиків та 57 TM із 16 підгруп антидепресантів, спостерігається розходження 3 формулярними статтями в частині інформації щодо застосування у жінок при вагітності та у період грудного вигодовування. Серед них лише для ТМ Амісульприду вказано на протипоказання при годуванні груддю, але не зазначено застереження щодо періоду вагітності.

При детальному вивченні особливостей застосування зазначених в таблиці 2 TM IMЗ виявлено 33 тези стосовно періоду вагітності та 21 - щодо грудного вигодування, які містять стилістичні та семантичні розбіжності у тлумаченні цих постулатів. Для уніфрікації зазначені сукупності застережень були згруповані по 5 груп відповідно, а саме:

ISSN 2312-0967. Pharmaceutical review. 2019. № 3 
1. У період вагітності

1.1. Група «протипоказано або не застосовувати»: застосування у період вагітності протипоказано (№ TM 65, 123, 124); застосування протипоказане у період вагітності, особливо у I триместрі (№ 65); застосування під час вагітності або при підозрі на вагіт- ність протипоказано (№ 79); застосування вагітним жінкам протипоказано (№ 80 - 83); не слід застосовувати у період вагітності (№ 52); препарат не застосовують у період вагітності (№ 57, 69 - 71); бажано не призначати в останньому триместрі вагітності, його призначають тільки у невідкладних випадках,

\section{Таблиця 2}

Особливості застосування у жінок під час вагітності та після пологів лз за даними ІМЗ лз

\begin{tabular}{|c|c|c|}
\hline \multirow[t]{2}{*}{$\begin{array}{c}\text { МНН і ТМ Л3 } \\
\text { (протипоказання за даними ДФ лЗ) }\end{array}$} & \multicolumn{2}{|c|}{$\begin{array}{c}\text { Особливості } \\
\text { застосування за даними IM3 л3 } \\
\text { у період }\end{array}$} \\
\hline & вагітності & $\begin{array}{l}\text { годування } \\
\text { груддю } \\
\end{array}$ \\
\hline 1 & 2 & 3 \\
\hline \multicolumn{3}{|l|}{ N05A Антипсихотики } \\
\hline \multicolumn{3}{|l|}{ N05A L05 Амісульприд* } \\
\hline 1. Солерон 100, 200 (ТОВ «Фарма Старт», Україна) & \multirow{4}{*}{1.3} & \multirow{4}{*}{2.1} \\
\hline 2. Солекс® (Рівофрарм СА, Швейцарія) & & \\
\hline 3. Соліан® (Юнітер Ліквід Манусрекчурінг, Франція) & & \\
\hline 4. Соліан® 200 мг (Дельфрарм Діжон, Франція) & & \\
\hline \multicolumn{3}{|l|}{ N05A X12 Арипіпразол } \\
\hline 5. Абізол (Нобел Ілач Санаї Ве Тіджарет А.Ш., Туреччина) & \multirow{6}{*}{1.5} & 2.1 \\
\hline 6. Амдоал (ВАТ «Гедеон Ріхтер», Угорщина) & & 2.5 \\
\hline 7. Арип МТ (Торрент Фармасьютікалс Лтд, Індія) & & \multirow{4}{*}{2.1} \\
\hline 8. Арипразол (ТОВ «Фарма Старт», Україна) & & \\
\hline 9. Арілентал (Актавіс Лтд., Мальта) & & \\
\hline 10. Аріпрадекс (АТ «Лабораторіос Нормон», Іспанія) & & \\
\hline 11. Зилаксера (КРКА, д.Д., Ново место, Словенія) & 1.4 & 2.2 \\
\hline $\begin{array}{l}\text { 12. Міріум (Сінтон Хіспанія С.Л., Іспанія; Джі І Фармасьютікалс, Лтд, Болгарія; } \\
\text { Квінта-Аналітика с.р.о, Чеська Республіка; Лабор Л+С АГ, Німеччина; ІТЕСТ } \\
\text { плюс, с.р.о., Чеська Республіка) }\end{array}$ & \multirow[t]{3}{*}{1.5} & 2.1 \\
\hline 13. Піпзол 10 (Алємбік Фармас'ютікелс Лімітед, Індія) & & 2.2 \\
\hline 14. Фрейм (ПАТ «Фармак», Україна) & & 2.1 \\
\hline \multicolumn{3}{|l|}{ N05A D01 Галоперидол } \\
\hline 15. Галоперидол деканоат (ВАТ «Гедеон Ріхтер», Угорщина) & \multirow[t]{3}{*}{1.2} & \multirow{3}{*}{2.5} \\
\hline 16. Галоперидол Ріхтер (ВАТ «Гедеон Ріхтер», Угорщина) & & \\
\hline 17. Галоперидол фрорте (ВАТ «Гедеон Ріхтер», Угорщина) & & \\
\hline 18. Галоприл (ТзОВ «ХФП «Здоров’я народу», Україна) & \multirow[t]{2}{*}{1.5} & \multirow[t]{2}{*}{2.1} \\
\hline 19. Галоприл фрорте (ТзОВ «ХФП «Здоров'я народу», Україна & & \\
\hline \multicolumn{3}{|l|}{ N05A E04 Зипразидон } \\
\hline $\begin{array}{l}\text { 20. Зелдокс® (Р-Фарм Джермані ГмбХ, Німеччина; } \\
\text { Пфрайзер Ірландія Фармасьютікалз, Ірландія) }\end{array}$ & 1.4 & 2.2 \\
\hline \multicolumn{3}{|l|}{ N05AF05 Зуклопентиксол } \\
\hline 21. Клопіксол (Х. Лундбек A/C, Данія) & \multirow{3}{*}{1.4} & \multirow{3}{*}{2.3} \\
\hline 22. Клопіксол Депо (Х. Лундбек A/C, Данія) & & \\
\hline 23. Клопіксол-Акуфраз (Х. Лундбек А/C, Данія) & & \\
\hline
\end{tabular}

ISSN 2312-0967. Фармацевтичний часопис. 2019. № 3 
Продовження табл. 2

\begin{tabular}{|c|c|c|}
\hline 1 & 2 & 3 \\
\hline \multicolumn{3}{|l|}{ N05A H04 Кветіапін } \\
\hline $\begin{array}{l}\text { 24. Квентіакс® (КРКА, д.д., Ново место, Словенія } \\
\text { КРКА-срарма д.о.о, Хорватія) }\end{array}$ & \multirow{8}{*}{1.5} & \multirow{3}{*}{2.5} \\
\hline $\begin{array}{l}\text { 25. Квентіакс® SR (КРКА, д.Д., Ново место, Словенія } \\
\text { КРКА-срарма д.о.о, Хорватія) }\end{array}$ & & \\
\hline 26. Кветиксол (Актавіс Лтд., Мальта) & & \\
\hline 27. Кветирон 25,100,200 (ТОВ «Фарма Старт», Україна) & & 2.1 \\
\hline 28. Кветирон XR 50,200,400 (ТОВ «Фарма Старт», Україна) & & 2.5 \\
\hline 29. Кветіпін (Фармасайнс Інк., Канада) & & 2.1 \\
\hline 30. Кетилепт® (ЗАТ ФЗ ЕГІС, Угорщина) & & \\
\hline 31. Кетилепт® Ретард (ЗАТ ФЗ ЕГІС, Угорщина) & & 2.5 \\
\hline \multicolumn{3}{|l|}{ N05А Н02 Клозапін } \\
\hline 32. Азалептол (ПрАТ «Технолог», Україна) & \multirow[t]{2}{*}{1.5} & \multirow[t]{2}{*}{2.5} \\
\hline 33. Азапін (АТ «Київський вітамінний завод», Україна) & & \\
\hline \multicolumn{3}{|l|}{ N05А Н03 Оланзапін } \\
\hline 34. Адажио® (ПАТ «Фармак Україна) & \multirow{7}{*}{1.5} & \multirow{4}{*}{2.2} \\
\hline 35. Еголанза (ЗАТ ФЗ ЕГІС, Угорщина) & & \\
\hline $\begin{array}{l}\text { 36. Заласта ® Qtab® (KРКА, д.Д., Ново место, Словенія } \\
\text { KРКА, Польща Сп.3.о.о., Польща) }\end{array}$ & & \\
\hline $\begin{array}{l}\text { 37. Заласта® (КРКА, д.Д., Ново место, Словенія } \\
\text { КРКА, Польща Сп.з.о.о., Польща) }\end{array}$ & & \\
\hline $\begin{array}{l}\text { 38. Золафррен (Заклад Фармацевтичний Адамед Фарма С.А., Польща; } \\
\text { Паб'яніцький фрармацевтичний завод Польфра А.Т, Польща) }\end{array}$ & & 2.2 \\
\hline 39. Оланзапін (Джубілант Дженерікс Лтд, Індія) & & \multirow[b]{2}{*}{2.2} \\
\hline $\begin{array}{l}\text { 40. Парнасан® (ВАТ «Гедеон Ріхтер», Угорщина } \\
\text { ТОВ «Гедеон Ріхтер Польща», Польща) }\end{array}$ & & \\
\hline \multicolumn{3}{|l|}{ N05АХ13 Паліперидон } \\
\hline 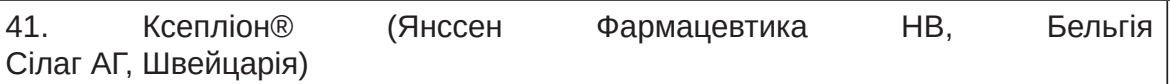 & 1.3 & 2.1 \\
\hline \multicolumn{3}{|l|}{ N05A Х08 Рисперидон } \\
\hline $\begin{array}{l}\text { 42. Ерідон (Дар Аль Дава Девелопмент енд Інвестмент Ко. Лтд., Йорданія; } \\
\text { Шанель Медікал, Ірландія) }\end{array}$ & \multirow{4}{*}{1.3} & \multirow{4}{*}{2.1} \\
\hline 43. Нейриспін - Здоров’я (ТзОВ ФК «Здоров’я», Україна) & & \\
\hline 44. Риспаксол® (АТ «Гріндекс», Латвія) & & \\
\hline 45. Риспетрил (Фармасайнс Інк., Канада) & & \\
\hline 46. Рисполепт Конста® (Сілаг АГ, Швейцарія; Алкермес Інк., США) & 1.3 & 2.4 \\
\hline 47. Риссет® (Меркле ГмбХ, Німеччина) & 1.4 & \\
\hline 48. Риссет® (Пліва Хрватска д.о.о., Хорватія) & & 2.1 \\
\hline 49. Рілептид® (ЗАТ ФЗ ЕГІС, Угорщина) & 1.3 & \\
\hline 50. Сізодон 2,4 (Сан Фармасьютикал Індастріз Лтд., Індія) & & \\
\hline 51. Торендо® Q-Тab® (КРКА, Д.Д., Ново место, Словенія) & & 2.4 \\
\hline N05A Е03 Сертиндол & & \\
\hline 52. Сердолект (Х. Лундбек А/C, Данія) & 1.1 & 2.1 \\
\hline
\end{tabular}

ISSN 2312-0967. Pharmaceutical review. 2019. № 3 
Фармакоекономіка

Pharmacoeconomics

Продовження табл. 2

\begin{tabular}{|c|c|c|}
\hline 1 & 2 & 3 \\
\hline \multicolumn{3}{|l|}{ N05A L01 Сульпірид } \\
\hline 53. Бетамакс (АТ «Гріндекс», Латвія) & \multirow{4}{*}{1.2} & \multirow{4}{*}{2.2} \\
\hline 54. Еглоніл® (Дельфарм Діжон, Франція) & & \\
\hline 55. Сульпірид (ТОВ Тева Оперейшнз Поланд, Польща) & & \\
\hline 56. Сульпірид-ЗН (ТОВ «ХФП «Здоров’я народу», Україна) & & \\
\hline \multicolumn{3}{|l|}{ N05A C02 Тіоридазин } \\
\hline 57. Сонапакс® 10, 25 мг (Фармзавод Єльфра А.Т., Польща) & 1.1 & 2.1 \\
\hline \multicolumn{3}{|l|}{ N05АВ02 Флуфеназин } \\
\hline 58. Модитен Депо (КРКА, д.Д., Ново место, Словенія) & 1.5 & 2.1 \\
\hline \multicolumn{3}{|l|}{ N05A F01 Флюпентиксол } \\
\hline 59. Флюанксол (Х. Лундбек А/C, Данія) & \multirow[t]{2}{*}{1.4} & \multirow[t]{2}{*}{2.3} \\
\hline 60. Флюанксол Депо (Х. Лундбек А/C, Данія) & & \\
\hline \multicolumn{3}{|l|}{ N05А А01 Хлорпромазин } \\
\hline 61. Аміназин (ПАТ «Галичфрарм», Україна) & \multirow{3}{*}{1.2} & \multirow{3}{*}{2.1} \\
\hline 62. Аміназин (ТОВ «ХФП «Здоров’я народу»,Україна) & & \\
\hline 63. Аміназин Здоров'я (ТзОВ «ФК»Здоров'я», Україна) & & \\
\hline \multicolumn{3}{|l|}{ N05A F03 Хлорпротиксен } \\
\hline 64. Труксал (Х. Лундбек А/C, Данія) & 1.4 & 2.3 \\
\hline \multicolumn{3}{|l|}{ N05A N01 Лimiŭ } \\
\hline 65. Глюталіт (ПАТ «НВЦ «Борщагівський ХФЗ», Україна) & 1.1 & 2.1 \\
\hline \multicolumn{3}{|l|}{ N05B Анксіолітики } \\
\hline \multicolumn{3}{|l|}{ N05B Е01 Буспірон } \\
\hline 66. Буспірон Сандоз® (Салютас Фарма ГмбХ, Німеччина) & \multirow[t]{2}{*}{1.5} & \multirow[t]{2}{*}{2.1} \\
\hline 67. Спітомін® (ЗАТ ФЗ ЕГІС, Угорщина) & & \\
\hline \multicolumn{3}{|l|}{ N05B А01 Діазепам } \\
\hline 68. Діазепекс® (АТ «Гріндекс», Латвія) & \multirow{4}{*}{1.1} & \multirow{4}{*}{2.1} \\
\hline 69. Діазепам-ЗН (ТОВ «ХФП «Здоров'я народу», Україна) & & \\
\hline 70. Сибазон (ТОВ «ХФП «Здоров'я народу», Україна) & & \\
\hline 71. Сибазон® IC (ТзОВ «Інтерхім», Україна) & & \\
\hline \multicolumn{3}{|l|}{ N06А Антидепресанти } \\
\hline \multicolumn{3}{|l|}{ N06A X22 Агомелатин } \\
\hline $\begin{array}{l}\text { 72. Мелітор (Лабораторії Сервє Індастрі, Франція Сервє (Ірландія) Індастріс } \\
\text { Лтд, Ірландія) }\end{array}$ & 1.2 & 2.5 \\
\hline \multicolumn{3}{|l|}{ N06A A09 Амітриптилін } \\
\hline $\begin{array}{l}\text { 73. Амітриптиліну гідрохлорид-ОЗ (ТОВ «ДЗ «ГНЦЛС» / ТОВ «ХФП «Здоров'я } \\
\text { народу» Україна) }\end{array}$ & 1.1 & \multirow[t]{3}{*}{2.3} \\
\hline 74. Амітриптилін (ПрАТ «Технолог», Україна) & \multirow{4}{*}{1.4} & \\
\hline 75. Амітриптилін (ТОВ «ФК «Здоров'я» / ТОВ «ДЗ «ГНЦЛС», Україна) & & \\
\hline 76. Амітриптиліну гідрохлорид (ТОВ «ХФП «Здоров'я народу», Україна) & & 2.1 \\
\hline 77. Саротен (Х. Лундбек А/C, Данія) & & 2.3 \\
\hline \multicolumn{3}{|l|}{ N06A X12 Бупропіон } \\
\hline $\begin{array}{l}\text { 78. Велбутрин }{ }^{\mathrm{TM}} \text { SR (ГлаксоСмітКляйн Фармасьютикалз С.A., Польща/ } \\
\text { ГлаксоСмітКляйн LLC, США) }\end{array}$ & 1.5 & 2.1 \\
\hline
\end{tabular}

ISSN 2312-0967. Фармацевтичний часопис. 2019. № 3 
Фармакоекономіка Pharmacoeconomics

Продовження табл. 2

\begin{tabular}{|c|c|c|}
\hline 1 & 2 & 3 \\
\hline \multicolumn{3}{|l|}{ N06A X16 Венлафаксин } \\
\hline 79. Алвента (КРКА, д.Д., Ново место, Словенія), & \multirow{6}{*}{1.1} & \multirow{4}{*}{2.1} \\
\hline 80. Велаксин (ЗАТ ФЗ ЕГІС, Угорщина) & & \\
\hline 81. Венлаксор (АТ «Гріндекс», Латвія) & & \\
\hline 82. Венлафраксин (ПрАТ «Технолог», Україна) & & \\
\hline 83. Венлафраксин-ЗН (ТОВ «ХФП «Здоров’я народу», Україна), & & \multirow[t]{2}{*}{2.5} \\
\hline 84. Медофаксин (Ципла Лтд, Індія; Медокемі ЛтД (Завод AZ), Кіпр) & & \\
\hline \multicolumn{3}{|l|}{ N06А А12 Доксепін } \\
\hline 85. Доксепін-ЗН, «ХФП «Здоров’я народу», Україна, & \multirow[t]{2}{*}{1.5} & \multirow[t]{2}{*}{2.1} \\
\hline 86. Доксепін (ТОВ Тева Оперейшенз Поланд, Польща) & & \\
\hline \multicolumn{3}{|l|}{ N06А Х21 Дулоксетин } \\
\hline 87. Дулокем 30 (Алкем Лабораторіз Лтд, Індія) & \multirow{5}{*}{1.4} & \multirow{6}{*}{2.2} \\
\hline 88. Дулоксента (КРКА, д.Д., Ново место, Словенія) & & \\
\hline 89. Дулот (Люпін Лімітед, Індія) & & \\
\hline 90. Дюксет (Нобел Ілач Санаї ве Тіджарет а.ш, Туреччина) & & \\
\hline 91. Дюлок® ПАТ «Фармак», Україна & & \\
\hline 92. Симода (Балкансрарма-Дупниця ад, Болгарія) & 1.5 & \\
\hline \multicolumn{3}{|l|}{ N06A B10 Есциталопрам } \\
\hline 93. Асіталокс (Ауробіндо Фарма Лімітед (Юніт ІІІ), Індія) & \multirow{14}{*}{1.4} & \multirow{14}{*}{2.2} \\
\hline 94. Депресан (ТОВ «ХФП «Здоров'я народу», Україна) & & \\
\hline 95. Езопрам (Актавіс Лтд, Мальта; Балканорарма-Дупниця АТ, Болгарія) & & \\
\hline 96. Еліцея (КРКА д.Д., Новоместо, Словенія) & & \\
\hline 97. Епракад (Джу білант Дженерікс Лімітед, Індія) & & \\
\hline 98. Ессобел® (Нобел Ілач Санаї Ве Тіджарет А.Ш., Туреччина) & & \\
\hline 99. Есциталопрам-ТЕВА (ТОВ Тева Оперейшнз Поланд, Польща) & & \\
\hline 100. Есцитам 10, 20, («Фарма Старт», Україна) & & \\
\hline 101. Есцитам® Асіно («Фарма Старт», Україна) & & \\
\hline 102. Ленуксин® (ТОВ «Гедеон Ріхтер Польща, Польща) & & \\
\hline $\begin{array}{l}\text { 103. Медопрам (Медокемі ЛтД (Завод АZ), Кіпр; } \\
\text { Фармацевтіш Аналітіш Лабораторіум Дуівен Б.В., Нідерланди) }\end{array}$ & & \\
\hline 104. Реціта-5,10,20 (Іпка Лабораторіз Лімітед, Індія) & & \\
\hline 105. Феліз С (Торрент Фармасьютікалс Лтд, Індія) & & \\
\hline 106. Ципрам® (Актав іс Лтд, Мальта) & & \\
\hline \multicolumn{3}{|l|}{ N06A A02 Іміпрамін } \\
\hline 107. Меліпрамін (ЗАТ ФЗ ЕГІС, Угорщина) & 1.1 & 2.1 \\
\hline \multicolumn{3}{|l|}{ N06A A04 Кломіпрамін } \\
\hline 108. Анафрраніл (Новартіс Фарма Штейн АГ, Швейцарія), & \multirow[t]{2}{*}{1.4} & \multirow[t]{2}{*}{2.1} \\
\hline 109. Клофраніл (Сан Фармасьютикал Індастріз Лтд, Індія) & & \\
\hline \multicolumn{3}{|l|}{ N06A Х03 Міансерин } \\
\hline 110. Міасер (Рівофрарм СА, Швейцарія) & 1.5 & 2.4 \\
\hline \multicolumn{3}{|l|}{ N06A B05 Пароксетин } \\
\hline 111. Паксил (ГлаксоСмітКляйн Фармасьютикалз С.А., Польща) & \multirow{3}{*}{1.5} & \multirow{3}{*}{2.4} \\
\hline 112. Пароксин (ТОВ «Фарма Старт», Україна) & & \\
\hline 113. Рексетин® (ВАТ «Гедеон Ріхтер») & & \\
\hline
\end{tabular}

ISSN 2312-0967. Pharmaceutical review. 2019. № 3 
Продовження табл. 2

\begin{tabular}{|c|c|c|}
\hline 1 & 2 & 3 \\
\hline \multicolumn{3}{|l|}{ N06A B06 Сертралін } \\
\hline 114. Асентра® (КРКА, Д.Д., Ново место, Словенія) & \multirow{7}{*}{1.3} & \multirow{7}{*}{2.4} \\
\hline 115. Емотон (СУІП «Сперко Україна») & & \\
\hline 116. Емотон (Атлантік Фарма, Португалія) & & \\
\hline $\begin{array}{l}\text { 117. Золофт® (Хаупт Фарма Латіна С.р.л., Італія; } \\
\text { Пфрайзер Менюфекчуринг Дойчленд ГмбХ, Німеччина) }\end{array}$ & & \\
\hline 118. Серліфт (Сан Фармасьютикал Індастріз Лімітед, Індія) & & \\
\hline 119. Сертралофт 100, 50, 25 (ТзОВ «ФК «Здоров'я», Україна) & & \\
\hline 120. Стимулотон® (ЗАТ ФЗ ЕГІС, Угорщина) & & \\
\hline \multicolumn{3}{|l|}{ N06A Х05 Тразодон } \\
\hline 121. Триттіко (А.К.Р.А.Ф. С.п.А., Італія) & \multirow[t]{2}{*}{1.5} & \multirow[t]{2}{*}{2.5} \\
\hline 122. Триттіко XR (А.К.Р.А.Ф. С.п.А., Італія) & & \\
\hline \multicolumn{3}{|l|}{ N06А В03 Флуоксетин } \\
\hline 123. Флуксен (ПАТ «Київмедпрепарат», Україна) & \multirow[t]{2}{*}{1.1} & \multirow[t]{2}{*}{2.1} \\
\hline 124. Флуоксетин (ТзОВ «ДЗ «ГНЦЛС»; «ФК «Здоров’я», Україна) & & \\
\hline \multicolumn{3}{|l|}{ N06А В08 Флувоксамін } \\
\hline $\begin{array}{l}\text { 125. Депривокс® (СТАДА Арцнайміттель АГ, Німеччина; } \\
\text { Роттендорфр Фарма ГмбХ, Німеччина; МПФ Б.В., Нідерланди) }\end{array}$ & \multirow[t]{2}{*}{1.4} & \multirow[t]{2}{*}{2.1} \\
\hline 126. Феварин® (Майлан Лабораторіз САС, Франція) & & \\
\hline \multicolumn{3}{|l|}{ N06A B04 Циталопрам } \\
\hline $\begin{array}{l}\text { 127. Ципраміл (Х. Лундбек A/C, Данія; Еурофрінс Біофарма Продакт Тестінг } \\
\text { Денмарк А/C, Данія) }\end{array}$ & \multirow[t]{2}{*}{1.4} & \multirow[t]{2}{*}{2.3} \\
\hline 128. Цита САНДОЗ® (Салютас Фарма ГмбХ, Німеччина) & & \\
\hline \multicolumn{3}{|l|}{ * годування груддю } \\
\hline
\end{tabular}

якщо очікуваний терапевтичний ефрект перевищує ризик (№ 68); у період вагітності протипоказаний (№ 73, 79, 84); приймання під час вагітності протипоказане (№ 107).

1.2. Група «уникати або не рекомендовано»: застосування у період вагітності не рекомендується (№ 53-56, 61 - 63); з метою попередження будь-яких ризиків бажано уникати приймання ЛЗ у період вагітності (№ 72); рекомендується уникати застосування ЛЗ під час вагітності (№ 15 - 17).

1.3. Група «не рекомендується без з'ясування коpuсті і ризику»: не рекомендується застосовувати у період вагітності, крім випадків, коли клінічний стан жінки такий, що очікувані переваги від застосування препарату перевищують потенційний ризик (№ 114 120); застосування не рекомендується, за винятком випадків, коли перевага перевищує ризик (№ 1-4); не рекомендується застосовувати під час вагітності, окрім випадків життєвої необхідності (№ 42 - 45, 48 51); не слід застосовувати у період вагітності, за винятком крайньої необхідності (№ 46); можна призначати вагітним тільки у разі нагальної потреби, зваживши користь і ризики (№ 41).
1.4. Група «не призначати без урахування співвідношення користі для матері/ризику для плода»: не можна застосовувати під час вагітності, крім випадків, коли це є вкрай необхідним (№ 47); не призначати у період вагітності, якщо тільки очікувана користь для пацієнтки не перевищує теоретичного ризику для плода (№ 21 - 23,74 - 77, 87 - 91); не рекомендується призначати вагітним, за винятком випадків, коли очікувана користь для матері $€$ більшою від потенційного ризику для плода (№ 20); не слід застосовувати лз у період вагітності, це виправдано лише у тому випадку, коли стан жінки потребує лікування Л3 (№ 125, 126); не слід застосовувати при вагітності, якщо тільки очікувана користь чітко виправдовує потенційний ризик для плода (№ 11); не слід призначати вагітним, за винятком випадків, коли після ретельного розгляду всіх недоліків і переваг була чітко доведена необхідність призначення препарату (№ 127, 128); не слід призначати у період вагітності, якщо тільки очікувана користь для пацієнтки не перевищує теоретичного ризику для плода (№ 59, 60, 64); протипоказаний вагітним, за винятком випадків, коли після ретель-

ISSN 2312-0967. Фармацевтичний часопис. 2019. № 3 
ного розгляду всіх ризиків і переваг була чітко доведена необхідність призначення препарату (№ 93 - 106); слід уникати застосування в період вагітності, за винятком тих випадків, коли очікуваний ефект від лікування для вагітної, безсумнівно, перевищує потенційний ризик для плода (№ 108, 109).

1.5. Група «можна призначати 3 урахуванням співвідношення користь для матері/ризик для плода»: застосовують лише у випадках, коли очікувана користь для матері перевищує потенційний ризик для плода (№ 86); застосування у період вагітності можливе тільки у тому випадку, якщо очікувана користь переважає можливий тератогенний ефект (№ 18, 19); можна застосовувати тільки у разі, коли очікувана користь для матері перевищує потенційний ризик для плода (№ 85); можна призначати тільки тоді, коли очікувана користь для вагітної перевищує потенційний ризик для плода (№ 5 - 10, 12, 14, 24, 25, 30 - 33, 66, 67, 78); можна приймати під час вагітності тільки за умови, що потенційна користь застосування перевищує потенційний ризик для плода (№ 13, 39, 58); необхідно застосовувати тільки тоді, коли очікувані результати виправдовують можливий ризик для плода (№ 34 - 38); при застосуванні Лз необхідно зважувати користь від його застосування для матері та можливий ризик для плода/новонародженого (№ 110); призначати Л3 тільки тоді, коли очікувана користь для матері перевищує потенційний ризик для плода (№ 111 - 113); призначення можливе тільки у разі, коли потенційна користь терапії для вагітної значно перевищує потенційний ризик для плода (№ 40); слід застосовувати 3 обережністю з урахуванням співвідношення користь для матері/ризик для плода (№ 121, 120); слід зважити можливу користь від такої терапії порівняно 3 потенційним ризиком для плода (№ 29); слід призначати лише у випадках, коли очікувана користь для матері перевищує можливий ризик для плода (№ 26, 27); слід призначати, тільки якщо очікувана користь виправдовує потенційний ризик (№ 28); слід приймати під час вагітності, тільки якщо потенційні переваги виправдовують потенційний ризик для плода (№ 92).

\section{2. У період годування груддю}

2.1. Група «протипоказано»: застосування в період годування груддю протипоказано (№ 1 - 4, 29, 79, 107, 123, 124); застосування при годуванні груддю протипоказано; у разі необхідності застосування препарату годування груддю слід припинити (№ 68, 80 82); не застосовують у період годування груддю (№ 69 - 71); не слід застосовувати протягом періоду годування груддю (№ 41); не слід призначати жінкам, які годують груддю (№ 125, 126); слід відмовитися від годування груддю (№ 11); під час лікування слід припинити годування груддю (№ 5,7 - 10, 12, 14, 18, 19, $27,42-45,47-50,52,57,58,61-63,65-68,76,78$, $85,86,108,109)$.
2.2. Група «не рекомендується або утриматись від годування»: годування груддю під час приймання не рекомендується (№ 34 - 37, 39, 40, 53 -56, 87 106); годувати груддю при застосуванні препарату не рекомендується (№ 13); пацієнткам слід утримуватись від годування груддю під час застосування лз (№ 20); рекомендується не годувати немовлят груддю (№ 38).

2.3. Група «годувати можна при нагляді за немовлям»: годування груддю можна продовжувати, але рекомендується спостереження за немовлям, особливо у перші 4 тижні після народження (№ 50, 60, $64,74-77)$; грудне годування може тривати у період лікування Л3, якщо це є клінічно важливим, але рекомендується нагляд лікаря за немовлям, особливо у перші чотири тижні після народження (№ 21, 22, 23); наявних даних недостатньо для оцінки ризику для дитини; рекомендується приймати 3 обережністю (№ 127, 128).

2.4. Група «урахування співвідношення користь для матері/ризик для дитини»: застосування у період годування груддю не рекомендоване, за винятком випадків, коли, на думку лікаря, користь від приймання препарату перевищує можливий ризик (№ 114 120); необхідно зважувати користь від його застосування для матері та можливий ризик для плода/новонародженого (№ 110); ніяких ознак впливу препарату на новонароджених не виявлено, однак лз не слід застосовувати в період годування груддю, крім випадків, коли очікувана користь для матері перевищує можливий ризик для дитини (№ 111 - 113); переваги годування груддю мають бути оцінені відносно потенційного ризику для дитини (№ 46, 51).

2.5. Група «або лікування або грудне вигодовування»: бажано припинити годування протягом лікування ЛЗ або припинити лікування на період годування груддю (№ 24, 25); жінкам необхідно рекомендувати припинити грудне вигодовування немовлят під час приймання Л3 (№ 26, 28, 30); жінки, які отримують лікування препаратом, не повинні годувати груддю (№ 32, 33); необхідно прийняти рішення щодо припинення годування груддю або припинення/утримання від терапії лз з урахуванням користі грудного вигодовування для дитини та переваги терапії для жінки (№ 6, 15 - 17, 31); рішення щодо припинення годування груддю або припинення/утримання від терапії лЗ слід приймати, враховуючи користь від годування груддю для дитини та користь від лікування для матері (№ 72, 83, 84, 121, 122).

Також виявлено значні різночитання змісту тексту у більшості ІМЗ ТМ-аналогів щодо застосування у період вагітності та годування груддю, окрім хімічних підгруп N05A L05 Амісульприд, N05A F05 Зуклопентиксол, N05A L01 Сульпірид, N05A F01 Флюпентиксол, N05A A01 Хлорпромазин, N05A H02 Клозапін N05B E01 Буспірон, N06A B10 Есциталопрам, N06A A04 Кломіпрамін, N06A B05 Пароксетин, N06A B06

ISSN 2312-0967. Pharmaceutical review. 2019. № 3 
Сертралін, N06A X05 Тразодон, N06A B03 Флуоксетин, N06A B08 Флувоксамін, N06A B04 Циталопрам (обидва періоди), N06A A12 Доксепін, N06A X21 Дулоксетин (грудне годування), N06A X16 Венлафраксин (при вагітності).

Висновок. На підставі порівняльного аналізу змісту текстів формулярних статей ДФ ЛЗ та IMЗ антидепресантів, антипсихотиків та анксіолітиків встановлені їхні семантичні та стилістичні розбіжності, що при ФТ ДР у жінок у випадку вагітності та грудного вигодовування може спричинити ризик несприятливого впливу на перебіг процесу вагіт- ності, а також до ризику негативного впливу на ембріон / плід та новонародженого і немовля. Для мінімізації асиметрії інфрормації (розбіжностей у тлумаченні особливостей застосування) у фрормулярних статтях ДФ ЛЗ та ІМЗ ТМ-аналогів Державному експертному центру МОЗ України варто здійснити уніфікацію підходів до стилістики та семантики текстового наповнення відповідних розділів зазначених нормативних документів.

Конфлікт інтересів: відсутній.

Conflicts of interest: authors have no conflict of interest to declare.

\title{
RESEARCH OF INFORMATION ASYMMETRY OF REGULATORY DOCUMENTS REGARDING DRUGS FOR THE PHARMACOTHERAPY OF DEPRESSIVE DISORDERS IN PREGNANT WOMEN AND WOMEN IN CHILDBIRTH
}

\section{B. P. Hromovyk, M. E. Matviychuk}

\author{
Danylo Halytsky Lviv National Medical University \\ hromovyk@gmail.com, maryana_matviychuk@ukr.net
}

The aim of the work. Comparative analysis of the content of formulary articles of state forms of medicines and IFU of antidepressants, antipsychotics and anxiolytics to protect against potential risks of pharmacotherapy of depressive disorders in the dyad mother-fetus child.

Materials and Methods. The research materials were the data of the Unified Clinical Protocol of Primary, Secondary and Tertiary Medical Care for the Depression Treatment, State Formular of Medicines (Eleventh Release), State Register of Medicines of Ukraine as of 10.08.2019, in particular, IFU brands of antidepressants, antipsychotics, and anxiolytics. Methods of contextual analysis, comparison, generalization were applied in the work of our research.

Results and Discussion. According to the study of the regulatory document for the pharmacotherapy of depression, the row of drugs is shown under the international nonproprietary name, namely 18 antidepressants, 19 antipsychotics, and 2 anxiolytics. At the same time, in Ukraine there were registered 80 antipsychotics, 101 antidepressants, 9 anxiolytics brands. But only 69 antipsychotics, 71 antidepressants, and 8 anxiolytics are included in State Formular of Medicines (Eleventh Release). However, in Ukraine, there are not registered brand names of Oxazepam and Chlordiazepoxide, as well as 15 brands from 12 subgroups of chemicals, although they are present in State Formular of Medicines. In this case, the considered State Forms of Medicines do not include the brand name from the subgroup Tianeptine.

Further analysis of the text contents of the formulary articles and IFU included in State Formular of Medicines showed that there are 128 brands, namely: 65 brands from 18 subgroups of antipsychotics, 6 brands from 2 subgroups of anxiolytics and 57 brands from 16 subgroups of antidepressants. There is a discrepancy with the formal articles regarding IFU in women during pregnancy and breastfeeding. Among them, only for brand name Amisulpride indicate contraindications for breastfeeding, but no warning is given regarding the period of pregnancy.

During the in-depth study of the application features, IFU of brands revealed 33 theses regarding the period of pregnancy and 21 theses on breastfeeding, containing stylistic and semantic differences in the interpretation of these postulates. For unification, the indicated sets of reservations were grouped into 5 groups, respectively: during pregnancy and lactation. Also, significant discrepancies in the text content were found in most IFU of analog brands for use during pregnancy and lactation, except for the chemical subgroups Amisulpride, Zuclopentixol, Sulpiride, Flupentixol Chlorpromazine, Clopinoprom, Esopin, Esopinol, Fluvoxamine, Citalopram (both periods), Doxepin, Duloxetine (breast feeding), Venlafaxine (during pregnancy).

Conclusions. Based on the text comparative analysis of the formulary articles of State Formular of Medicines and IFU of antidepressants, antipsychotics and anxiolytics, their semantic and stylistic differences are established, and pharmacotherapy of depressive disorders in women during pregnancy and breastfeeding can pose a threat to the adverse effects on the course of pregnancy, as well as at risk of negative effects on the embryo/fetus of both the newborn and the infant. To minimize the asymmetric information (discrepancies in the interpretation of the peculiarities of use) in the formulary articles of State Formular of Medicines and IFU of brands analogues, the State Expert Center of the Ministry of Health of Ukraine should unify approaches to the style and semantics of textual filling of the relevant sections of these regulatory documents.

ISSN 2312-0967. Фармацевтичний часопис. 2019. № 3 
Key words: depression; woman; pre- and postpartum periods; antidepressant; antipsychotic; anxiolytic; brand name; formulary article; instructions for use (IFU); asymmetric information.

\title{
ИССЛЕДОВАНИЕ АСИММЕТРИИ ИНФОРМАЦИИ НОРМАТИВНЫХ ДОКУМЕНТОВ В ОТНОШЕНИИ ЛЕКАРСТВЕННЫХ СРЕДСТВ ДЛЯ ФАРМАКОТЕРАПИИ ДЕПРЕССИВНЫХ РАССТРОЙСТВ У БЕРЕМЕННЫХ И РОЖЕНИЦ
}

\author{
Б. П. Громовик, М. Е. Матвийчук \\ Львовский национальный медицинский университет имени Данила Галицкого \\ hromovyk@gmail.com, maryana_matviychuk@ukr.net
}

Цель работы. Сравнительный анализ содержания текстов фрормулярных статей Государственного фрормуляра лекарственных средств (ГФ ЛС) и инструкций для медицинского применения (ИМП) антидепрессантов, антипсихотиков и анксиолитиков, показанных для фрармакотерапии (ФТ) депрессивных расстройств (ДР) у женщин, для ограждения от потенциальных рисков ФТ в диаде мать - плод / ребенка.

Материалы и методы. Материалы исследования: данные Унифицированного клинического протокола первичной, вторичной и третичной медицинской помощи для лечения депрессии, ГФ ЛС одиннадцатого выпуска, Государственный реестр лекарственных средств (ГР ЛС) Украины по состоянию на 10.08.2019, в частности ИМП ТМ антидепрессантов, антипсихотиков и анксиолитиков. В работе были применены методы контекстуального анализа, сравнения, обобщения.

Результаты и обсуждение. По данным изучения Унифицированного клинического протокола для ФТ депрессии показаны 18 антидепрессантов, 19 антипсихотических средств и 2 анксиолитиков по международным непатентированным названиям. При этом в Украине зарегистрировано 80 антипсихотических средств, антидепрессантов - 101, анксиолитиков - 9 торговых марок (ТМ). В свою очередь, ГФ ЛС одиннадцатого выпуска содержит 69 ТМ антипсихотических средств, 71 ТМ антидепрессантов и 8 ТМ анксиолитиков. В Украине не зарегистрированы ТМ Оксазепама и Хлордиазепоксида, а также 15 ТМ изучаемых ЛС с 12 подгрупп химических веществ, хотя они присутствуют в ГФ ЛС. При этом в ГФ ЛС не включены ТМ из подгруппы Тианептина.

Анализ содержания текстов формулярных статей и ИМП ЛС, включенных в ГФ ЛС, показал, что в 128 ТМ, а именно: 65 ТМ с 18 подгрупп антипсихотиков, 6 ТМ из 2 подгрупп анксиолитиков и 57 ТМ с 16 подгрупп антидепрессантов, наблюдается расхождение с формулярными статьями в части информации по применению у женщин при беременности и в периоде грудного вскармливания. Среди них только для ТМ Амисульприда указано на противопоказания при кормлении грудью, но не указано предостережение относительно периода беременности. При изучении особенностей применения ИМП исследуемых ТМ выявлено 33 тезиса относительно периода беременности и 21 - по грудному вскармливанию, содержащие стилистические и семантические различия в толковании этих постулатов. Для униорикации указанные совокупности оговорок были сгруппированы по 5 групп соответственно в период беременности и в период кормления грудью.

Также выявлены значительные разночтения содержания текста в большинстве ИМП ТМ-аналогов по применению в период беременности и кормления грудью кроме ТМ Амисульприда, Зуклопентиксола, Сульпирида, Флюпентиксола, Хлорпромазина, Клозапина Буспирона, Эсциталопрама, Кломипрамина, Пароксетина, Сертралина, Тразодона, Флуоксетина, Флувоксамина, Циталопрама (оба периода), Доксепина, Дулоксетина (грудное вскармливание), Венласраксина (при беременности).

Выводы. На основании сравнительного анализа содержания текстов фрормулярных статей ГФ ЛС и ИМП антидепрессантов, антипсихотиков и анксиолитиков установлены их семантические и стилистические разногласия, что при ФТ ДР у женщин в случае беременности и грудного вскармливания может создавать угрозу неблагоприятного влияния на ход процесса беременности, а также к риску негативного влияния на эмбрион / плод и новорожденного и младенца. Для минимизации асимметрии информации (расхождений в толковании особенностей применения) в фрормулярных статьях ГФ ЛС и ИМП ТМ-аналогов Государственному экспертному центру МЗ Украины следует осуществить унификацию подходов к стилистике и семантике текстового наполнения соответствующих разделов указанных нормативных документов.

Ключевые слова: депрессия; женщина; до- и послеродовой периоды; антидепрессант; антипсихотик; анксиолитик; торговая марка; срормулярная статья; инструкция по применению; асимметрия информации.

\section{Список літератури}

1. Адаптована клінічна настанова, заснована на доказах «Депресія (легкий або помірний депресивні епізо-

ди без соматичного синдрому або з соматичним синдромом)» [Електронний ресурс] /Державний експерт-

ISSN 2312-0967. Pharmaceutical review. 2019. № 3 
ний центр Міністерства охорони здоровя України; Асоціація психіатрів України, 2014. - Режим доступу : http://mtd.dec.gov.ua/images/dodatki/2014_1003_ Depresiya/2014_1003_AKN_Depresiya.pdf.

2. Державний реєстр лікарських засобів України [Електронний ресурс]. - Режим доступу : http://www.drlz.com.ua/.

3. Державний фрормуляр лікарських засобів. Випуск одинадцятий [Електронний ресурс]. - Pежим доступу : https://moz.gov.ua/uploads/2/11838dn_20190418_892_dod_1.pdf

4. Майдан І. С. Післяпологова депресія у породіль. Огляд сучасних даних / І. С. Майдан // Слово о здоровье. - 2017. - № 4. - С. $34-37$

5. Про затвердження Порядку проведення експертизи реєстраційних матеріалів на лікарські засоби, що подаються на державну реєстрацію (перереєстрацію), а також експертизи матеріалів про внесення змін до реєстраційних матеріалів протягом дії реєстраційного посвідчення : наказ МО3 України від 26.08.2005 № 426 [Електронний ресурс]. - Режим доступу : http://zakon2.rada.gov.ua/ laws/show/z1069-05.

6. Пушкарьова Т. М. Алгоритм скринінгової діагностики депресивних та тривожно-депресивних розладів у жінок під час вагітності та після пологів / Т. М. Пушкарьова, Н. Я. Скрипченко // Здоровье женщины. 2017. - №1 (117). - С. 62 - 65.

7. Унгурян Л. М. Зміст текстів інструкцій для медичного застосування препаратів-аналогів з погляду асиметрії інорормації та пов'язаних із ліками проблем / Л. М. Унгурян, В. Й. Кресюн, Б. П. Громовик / Одеський медичний журнал. -2013. - № 6. - С. 27 - 32.

8. Унісрікований клінічний протокол первинної, вторинної та третинної медичної допомоги для лікування депресії: наказ МО3 України від 25.12.2014 № 1003 [Електронний ресурс]. - Режим доступу : http:// mtd.dec.gov.ua/images/dodatki/2014_1003_Depresiya/2014_1003_YKPMD_Depresiya.pdf

9. Shunkina, S. Methadone as an alternative analgesic for palliative patients / S. Shunkina, B. Hromovyk // Pharmacia. - 2016. - Vol. 63, Issue 4. - P. 21-28.

\section{References}

1. Adaptovana klinichna nastanova, zasnovana na dokazakh "Depresiia (lehkyi abo pomirnyi depresyvni epizody bez somatychnoho syndromu abo z somatychnym syndromom)" [Elektronnyi resurs] /Derzhavnyi ekspertnyi tsentr Ministerstva okhorony zdorovia Ukrainy; Asotsiatsiia psykhiatriv Ukrainy, 2014. Available from: http:// mtd.dec.gov.ua/images/dodatki/2014_1003_Depresiya/2014_1003_AKN_Depresiya.pdf.

2. Derzhavnyi reiestr likarskykh zasobiv Ukrainy [Electronic resources]. Available from: http://www.drlz.com.ua/.

3. Derzhavnyi formuliar likarskykh zasobiv. Vypusk odynadtsiatyi [Electronic resources]. Available from: https:// moz.gov.ua/uploads/2/11838-dn_20190418_892_ dod 1.pdf

4. Maidan IS. Pisliapolohova depresiia u porodil. Ohliad suchasnykh danykh. Slovo o zdorove. 2017;4:34-7. Russian

5. Pro zatverdzhennia Poriadku provedennia ekspertyzy reiestratsiinykh materialiv na likarski zasoby, shcho podaiutsia na derzhavnu reiestratsiiu (perereiestratsiiu), a takozh ekspertyzy materialiv pro vnesennia zmin do reiestratsiinykh materialiv protiahom dii reiestratsiinoho

posvidchennia : nakaz MOZ Ukrainy vid 26.08.2005 № 426 [Electronic resources]. - Available from: http://zakon2.rada.gov.ua/ laws/show/z1069-05.

6. Pushkarova TM, Ckrypchenko Nla. Alhorytm skryninhovoi diahnostyky depresyvnykh ta tryvozhno-depresyvnykh rozladiv u zhinok pid chas vahitnosti ta pislia polohiv. Zdorove zhenshchyny. 2017;1(117):62-5. Russian

7.Unhurian LM, Kresiun VY, Hromovyk BP. Zmist tekstiv instruktsii dlia medychnoho zastosuvannia preparativanalohiv z pohliadu asymetrii informatsii ta poviazanykh iz likamy problem. Odeskyi medychnyi zhurnal. 2013;6:27-32. Ukrainian.

8. Unifikovanyi klinichnyi protokol pervynnoi, vtorynnoi ta tretynnoi medychnoi dopomohy dlia likuvannia depresii: nakaz MOZ Ukrainy vid 25.12.2014 № 1003 [Electronic resources]. - Available from: http://mtd.dec.gov.ua/images/dodatki/2014_1003_Depresiya/2014_1003_YKPMD_Depresiya.pdf

9. Shunkina S, Hromovyk B. Methadone as an alternative analgesic for palliative patients. Pharmacia. 2016; 63(4):21-8. Russian

\section{Відомості про авторів:}

Громовик Б. П. - д. фрармац. н., профресор, завідувач кафедри організації та економіки фрармації, Львівський національний медичний університет імені Данила Галицького, Львів, Україна. E-mail: hromovyk@gmail.com, ORCID: 0000-0002-6459-6021.

Матвійчук М. $\boldsymbol{\epsilon}$ - аспірант кафедри організації та економіки фрармації Львівський національний медичний університет імені Данила Галицького, Львів, Україна. E-mail: maryana_matviychuk@ukr.net, ORCID: 0000-0002-70635832

Information about the authors:

Hromovyk B. P. - DS (Pharmacy), Professor, Head of the Organization and Economics of Pharmacy Department, Danylo Halytsky Lviv National Medical University, Lviv, Ukraine. E-mail: hromovyk@gmail.com, ORCID: 0000-0002-6459-6021.

Matviychuk M. Ye. - PhD-student of the Organization and Economics of Pharmacy Department, Danylo Halytsky Lviv National Medical University, Lviv, Ukraine. E-mail: maryana_matviychuk@ukr.net, ORCID: 0000-0002-7063-5832

ISSN 2312-0967. Фармацевтичний часопис. 2019. № 3 